\title{
“THIS OLD THEORY BROACH'D ANEW": Darwinism and Whitman's Poetic Program
}

\author{
HerTha D. WONG
}

WHEN JOHN BURROUGHS, a nineteenth-century naturalist and friend of Whitman, pondered the "stupendous disclosures of modern science," he concluded that they "have not yet furnished to any considerable extent the inspiration of poems." 1 New scientific awareness had altered religious beliefs; now, Burroughs insisted, literature had to follow suit: "If we ask where is the modern imaginative work that is based upon these revelations of science, the work in which they are the blood and vital juices, I answer, 'Leaves of Grass,' and no other" (WS, 250). Contemporary literary critics and scientists such as Joseph Beaver and Lenny Emmanuel agree with Burroughs, hailing Whitman as "the poet of science" and as "an interpreter for science and scientists." Writing during the time "science" as we know it today was coming into being, Whitman was one of the first poets to attempt to reconcile poetry and science. He stated his intention as early as the 1855 Preface to Leaves of Grass:

Exact science and its practical movements are no checks on the greatest poet, but always his encouragement and support. ... [Scientists] are the lawgivers of poets, and their construction underlies the structure of every perfect poem. No mattèr what rises or is utter'd, they sent the seed of the conception of it - of them and by them stand the visible proofs of souls . . . always of their fatherstuff must be begotten the sinewy races of bards. If there shall be love and content between the father and the son ... there shall be love between the poet and the man of demonstrable science. In the beauty of poems are henceforth the tuft and final applause of science. ${ }^{3}$

From the very beginning, Whitman decided not only to sing and celebrate science in his poetry, but to apply the natural laws of the physical world to poetics. The laws of nature, as revealed through science, would determine the laws of poetry.

Whitman was not merely interested in the application of the laws of nature to poetry, however, but in how he could apply science to arrive at a personalized and comprehensive vision of the universe. Since for Whitman "the supreme and final science is the science of God" and "what we call science [is] only its minister," 4 the purpose of science is to bring us closer to an understanding of God. It is science, which Whitman sees as the study of nature and the minister of God, that "prepares the way for . . . the new theology" $(P W$ $1872,462)$.

Arising from this union of "the poet and the man of demonstrable science" is Whitman's new political vision. The germinal religious potency, or soul, within each individual, enlivened by science and incorporated into poetry, would result in an ideal democratic citizen and ultimately in a future 
ideal democracy. As well as singing of science and religion, Leaves of Grass intends to be "the song of a great composite democratic individual . . . [and] the thread-voice ... of an aggregated, inseparable, unprecedented, vast, composite, electric democratic nationality" ( $P W 1872,463)$. In Leaves of Grass, then, Whitman aims to unify science (materialism) and religion (spiritualism) and thereby create "robust" individuals in an ideal democracy.

Whitman seeks to accomplish this apocalyptic vision through language, and one of the major techniques he uses is that of physical evolution as an analogue for spiritual evolution. Justin Kaplan notes that "absorbing the spirit of the times," Whitman "is already an evolutionist when Darwin publishes Origin of Species." 5 Although Whitman was probably influenced initially by Lamarckian evolution, by the 1870s he clearly associates Darwin with the theory of evolution. Further, he elevates Darwin to the status of an apostle of the angelic hosts of scientists. ${ }^{6}$ In order to marry science and religion through his evolutionary analogue, Whitman must unify body and soul so that the process of evolution incorporates both at once. The traditional Western concept of the gap between body and soul may have been bridged for Whitman by his interest in phrenology which emphasizes the reciprocity of physiology and spirituality. ${ }^{7}$ In Hereditary Descent, a book first published in 1843 by the well-known phrenologist, Orson S. Fowler, we find: "CHARACTER IS AS SHAPE. Given forms of body always accompany certain instincts and mental predilections . . . and both [are] equally transmissible." 8 Whitman knew the Fowler brothers, the first distributors of Leaves of Grass, and he was familiar with Hereditary Descent which proposes that the mind is equivalent to the body. Whitman, however, takes this a step further and equates the soul and the body, and by extension the spiritual and the material as well. He writes: "Was somebody asking to see the soul?/See, your own shape and countenance" $(L G, 23)$. Despite his ill health in later life (which directly challenged such a notion), Whitman seems to have retained his belief that the body is a reflection of the soul.

Sensitive to Whitman's special blend of spirituality and physicality, Emerson is said to have found in Leaves of Grass a "curious mixture of the Bhagavad-Gita and the New York Herald. ${ }^{9}$ In keeping with this seeming polarity, Whitman uses the language of Darwinian physical evolution to describe the mechanics of a spiritual evolution which often seems to parallel Eastern mysticism. ${ }^{10}$ This is not to say that Whitman wholeheartedly propounds an Eastern viewpoint, but as a part of his interest in a composite universal theology, these ideas filter into his thinking. His evolutionary passages resonate with the implications of a dual evolutionary process - body and soul, individual and cosmic.

In his conversations with Whitman, Horace Traubel supplies more insight into how completely Whitman merges the physical and the spiritual. When Traubel mentions that the contemporary evolutionist, Thomas Henry 
Huxley, said that he holds evolution not as a dogma, but as a working hypothesis, Whitman exclaims:

It is beautiful-beautiful-such a confession as that: the most glorious and satisfying spiritual statement of the nineteenth century. Can the churches, the priests, the dogmatists, produce anything to match it? How can we ever forget Darwin? Was ever a great man a more simple man than Darwin? Was ever a beautiful character a more simple character than Darwin? He is one of the acme men-he was at the top. I could hope for no better fate for my book than that it should grow strong in so beneficent an atmosphere-breathe the breath of its life. ${ }^{11}$

In this instance, science replaces traditional religion and is itself a "spiritual statement."

In another conversation with Traubel, Whitman directly unites poetry and evolution: "I always put the two together: Emerson, Darwin: Darwin was sweetly, grandly non-opinionative" (WWC, 2:517). By associating Emerson, from whom he derives at least a part of his concept of spiritual evolution, and Darwin, from whom he corroborates and expands his concept of physical evolution, he once again unites the "great constituent elements" of his poetry - "Materialism" and "Spirituality."12 Continuing this conversation, Whitman exalts both Emerson and Darwin as savants:

I like the style - the style of all the greatest sages-Epicurus, Epictetus, Emerson, Darwin: the modesty-the readiness to yield, to see what they might have excuses for not seeing. All modern science is saturated with the same spirit, and in this exists its excuse for being (WWC, 2:517).

Seers both, the poet and the scientist share a common gift-the ability to transcend the limitations of a pre-conditioned perception. Whitman himself is an embodiment of this idea. Burroughs describes him thus: "He is both Darwinian and Dantesque. He is the great reconciler" (WS, 264).

In an essay entitled "Darwinism-Then Furthermore," which first appeared in Troo Rivulets (1876), Whitman recognizes the far-reaching influence that Darwin's theory of evolution would have on intellectual history:

Of this old theory, evolution, as broach'd anew, trebled, with indeed all-devouring claims, by Darwin, it has so much in it, and is so needed as a counterpoise to yet widely prevailing and unspeakably tenacious, enfeebling, superstitions-is fused, by the new man, into such grand, modest, truly scientific accompaniments - that the world of erudition, both moral and physical, cannot but be eventually better'd and broaden'd in its speculations, from the advent of Darwinism. ${ }^{13}$

However, he also recognizes that the theory of evolution does not, in fact, explain "the problem of origins, human and other, ... leaving the divine secrets just as inexplicable and unreachable as before-may-be more so" (DTF, 524). Even though Whitman acknowledges that Darwin's theory of evolution does not explain every aspect of the development of human existence, he enthusiastically incorporates many of its basic tenets into his writing. 
Further evidence of this is found in a conversation Whitman had with Traubel. Near the end of his life, Whitman states:

I assume that Spencer, Huxley, Darwin, the greatest evolutionists everywhere, take the ground that evolution is a process: do not pretend that it gives a why for existence: no: only that it expresses a method of nature. ... I have felt from the first that my own work must assume the essential truths of evolution, or something like them $(W W C, 3: 94)$.

Likewise, in the poem "L. of G.'s Purport," he states that he does not wish "to exclude or demarcate, or pick out evils," but rather to "add, fuse, complete, extend-and celebrate the immortal and the good." He adds:

\author{
Haughty this song, its words and scope, \\ To span vast realms of space and time, \\ Evolution-the cumulative-growths and generations $(L G, 555)$.
}

Whitman consciously applies "the Evolution theory" throughout his work, and it is fitting that he should do so since it does not discriminate, but encompasses all. The process of evolution, in which the present continually absorbs the cumulative development of all past ages and prepares to project itself into the future, is also the process of Whitman's Leaves of Grass in which the persona "absorbs," "adds," "completes," "extends," "fuses," and finally "merges" not only with all of nature, but with the entire universe as well. This principle of evolutionary adhesiveness informs Whitman's numerous catalogues, parallelisms, serial conjunctions, and long lines as well. Each of these stylistic devices parallels the cumulative process of evolution.

In much of his poetry Whitman assumes the "truths of evolution" which, according to Darwin, rest on four fundamental assumptions: 1) the world is not static, but evolving; 2) the process of evolution is gradual and consistent; 3) similar organisms are related, descended from a common ancestor; and 4) evolutionary change is the result of a two-step process known as natural selection-the first step is the production of abundant variation; the second step is selection through survival in the "struggle for existence." 14 The first two postulates were shared by both Lamarck and Darwin, but the second two postulates were entirely new and revolutionary. Whereas Lamarck conceives of the frequent occurrence of spontaneous generation, Darwin believes that all organisms, including humans, descended from a common ancestor; and whereas Lamarck believes in an inherent drive for perfection within each organism, Darwin replaces such a drive with his theory of natural selection. Although some people interpret Darwin's natural selection as a brutal diminishing of human grace, Darwin himself sees "grandeur in this view of life" because, "from so simple a beginning endless forms most beautiful and most wonderful have been, and are being evolved." 15 Whitman shared Darwin's aesthetic appreciation of the evolutionary impulses of nature. Numerous pas- 
sages from Whitman's poetry and prose parallel Darwin's four basic postulates and his optimism.

Whitman decidedly agrees with Darwin's first assumption that the world is continually changing and developing. In Specimen Days he writes:

One of my cherished themes for a never-achiev'd poem has been the two impetuses of man and the universe - in the latter, creation's incessant unrest, exfoliation, (Darwin's evolution, I suppose.) Indeed, what is Nature but change, in all its visible, and still more its invisible processes? 16

In a footnote, Whitman expounds on how "the processes of growth, of existence, of decay, whether in worlds, or in the minutest organisms, are but motion" (SD, 289).

Closely related to the concept of continuous change is the idea that this change takes place over time - that it is gradual and consistent and not due to a series of creations. Darwin says that it is more reasonable to think that the "birth and death of individuals should be the effect of secondary [laws] means" because "it is derogatory that the Creator of countless systems of worlds should have created each of the myriads of creeping parasites and [slimy] worms which have swarmed each day of life on land and water on [this] one globe."17 Whitman reveals a parallel view in "Who Learns My Lesson Complete?":

It is no small matter, this round and delicious globe . . .,

I do not think it was made in six days, nor in ten thousand years, nor ten billions of years, Nor plann'd and built one thing after another as an architect plans and builds a house.

I do not think seventy years is the time of a man or woman,

Nor that seventy millions of years is the time of a man or woman,

Nor that years will ever stop the existence of me, or any one else $(L G, 394)$.

Whitman believes that the earth was not created all at once, but rather that it evolved over vast periods of time. He expands this evolution to include human souls who cannot be limited to an earthly life span because they are the culmination of the past and the seed of the future, and therefore are, in some sense, eternal.

Since Whitman believes that present conditions are the result of the effect of countless influences from the past, he can easily incorporate Darwin's third postulate, common descent. Scientist-writer Loren Eiseley states that in the nineteenth century, "The fallen Adam had stared into the mirror of nature and perceived there only the mocking visage of an ape."18 Unlike many of his contemporaries, the idea of a mutual progenitor does not shatter the dignity of humankind for Whitman, but rather delights his democratic sensibilities. He finds in the theory of evolution a powerful equalizer because it emphasizes the interconnectedness of everything in the universe. For instance, Whitman lovingly accepts his relationship with the animal kingdom: 
So they show their relations to me and I accept them,

They bring me tokens of myself, they evince them plainly in their possession.

I wonder where they get those tokens,

Did I pass that way huge times ago and negligently drop them?

Myself moving forward then and now and forever,

Gathering and showing more always and with velocity,

Infinite and omnigenous, and the like of these among them,

Not too exclusive toward the reachers of my remembrancers,

Picking out here one that I love, and now go with him on brotherly terms $(L G, 60)$.

"Infinite" and "omnigenous," Whitman suggests reincarnation, a spiritual evolution corresponding to the physical. He incorporates all time and all species, and he loves these evolutionary ancestors as brothers.

Whitman not only acknowledges his animal past, he recognizes his relationship with the entire range of the cosmos-mineral, vegetable, and animal. He writes: "I find I incorporate gneiss, coal, long-threaded moss, fruits, grains, esculent roots, / And am stucco'd with quadrupeds and birds all over ..." $(L G, 59)$. Whitman's persona does not merely nod intellectually to his evolutionary past but rather embraces it wholeheartedly. Nature cannot be separate from him because he absorbs and contains it all.

Whitman's use of the evolutionary theory closely parallels the first three postulates of Darwin's theory of development, but he does not so evidently express the fourth assumption - natural selection - which states that nature supplies an abundance of variety and those organisms most fit for their environment will survive and reproduce. The first of the two steps of "natural selection" - the initial fecundity and variety of nature - is easier for Whitman to incorporate into his thinking. He says, "I resist any thing better than my own diversity" ( $L G, 45)$, and he applies this understanding of the necessity of variety to his writing ("Let others finish specimens ... I start them by exhaustless laws as Nature does" [ $L G, 237])$.

The second stage of natural selection, the "struggle for existence," is less frequently found in Whitman's writing. But in "The World Below the Brine," a poem about evolution, Whitman presents a clear biological image of the "struggle for life" when he describes the plant and animal life in the primordial "forests at the bottom of the sea" and the "passions ... wars, pursuits, ... in those ocean-depths" $(L G, 260)$. Joseph Beaver points out the relevance of the sea as what scientists believe is the literal source of life ("the primordial soup") and Whitman's use of the sea as the "savage mother" (PS, 116). Similarly, in "Starting From Paumanok," Whitman combines the concepts of the biological "struggle for existence" and "survival of the fittest" when he discusses, from a more troubling perspective, what he sees as the disappearance of the "red aborigines" in the United States. He writes about a "new race dominating previous ones and grander far, with new contests ..." $(L G, 27)$. Here, rather than mourning the destruction of aboriginal peoples, 
Whitman glorifies what he sees as the new dominant race. ${ }^{19}$ When Traubel asks Whitman about "racial amalgamation," Whitman replies that blacks and Native Americans "will be eliminated: it is the law of races, history, whatnot. .. . Someone proves that a superior grade of rats comes and then all the minor rats are cleared out." When Traubel comments, "That sounds like Darwin," Whitman responds: "Does it? It sounds like me, too" ( $W W C$, $2: 283)$.

Overall, though, Whitman is not attracted to Darwin's notion of natural selection. Selection itself implies choice and preference which lead to exclusion. Since Whitman is prone to emphasize equality and all-inclusiveness, it seems natural that he would avoid excessive use of this concept. There is, however, one aspect of selection which Whitman does emphasize and that is sexual selection. Whitman makes "short account of neuters and geldings, and favor[s] men and women fully equipt" $(L G, 52)$. Throughout "Song of Myself" he celebrates this ever-evident "procreant urge of the world" which insures the continuity of the species. While he exalts active sexuality, Whitman nevertheless advocates selectivity in choosing a mate. He believes "that exaggerations will be sternly revenged in your own physiology," and insists "that clean-shaped children can be jetted and conceived only where natural forms prevail . .." $(L G, 599)$. Whitman wants only the most healthy, full-bodied, vital, physically and mentally fit individuals to produce offspring - "robust" offspring. If, as Darwin implies and Orson Fowler states, "Character is as shape," then mental as well as physical qualities are passed on. Sexual selection, then, becomes an important consideration. In a spiritual sense, this process can be likened to Emerson's concept of the "Oversoul" in which the divine soul pushes out through, and into, the material world. For Whitman the physical world is the means for understanding the spiritual. In fact, "the dumb beautiful ministers" of the material world reveal the deepest truths.

In the Darwinian theory of evolution there is no inherent concept of progress or purpose, but rather development is based on change and struggle. As a result, many individuals despaired over the loss of the comforting idea of "divine design." Darwin, however, sees a purposeful direction to evolution:

And as natural selection works solely by and for the good of each being, all corporeal and mental endowments will tend to progress towards perfection. ... Thus, from the war of nature, from famine and death, the most exalted object we are capable of conceiving, namely, the production of the higher animals, directly. follows (OS, 450).

Even Darwin recognizes "progress towards perfection," not like Lamarck due to an internalized drive for perfection, but because the most fit survive and reproduce and thus insure an endless process of refinement.

While Darwin limits his pinnacle of evolution to "the production of the higher animals," Whitman, under no such scientific restraint, announces to the reader: "The whole theory of the universe is directed unerringly to one 
single individual-namely to You" ( $L G, 352)$. He insists on the priceless value of each individual life. In "I Sing the Body Electric," as a "man's body" is about to be auctioned off, the persona exclaims:

Gentlemen look on this wonder,

Whatever the bids of the bidders they cannot be high enough for it,

For it the globe lay preparing quintillions of years without one animal or plant,

For it the revolving cycles truly and steadily roll'd $(L G, 98)$.

All the vast ages, all the geological strata, all the cumulative developments culminate in each individual - "Each of us inevitable!" $(L G, 147)$ and eternal. "I swear I think there is nothing but immortality!" exclaims Whitman, "That the exquisite scheme is for it, and the nebulous float is for it, and the cohering is for it!/And all preparation is for it-and identity is for it-and life and materials are altogether for it!" $(L G, 440)$.

Just as the individual is the culmination of evolution, the present is the fulfillment of the past. Seeking the "clew to the history of the past," Whitman concludes: "It is in the present .../It is in Democracy-(the purport and aim of all the past,)/It is the life of one man or one woman to-day" (LG, 387-388). The purpose of evolution, then, is in the present moment -in the life of each and every individual, in Democracy, and Whitman goes on to say, in language.

As a poet, Whitman is interested in the origin and development of words. Not surprisingly, he applies the theory of evolution to language as readily as he does to nature, religion, and politics. In his essay, "Slang in America," he writes: "The science of language has large and close analogies in geological science, with its ceaseless evolution, its fossils, and its numberless submerged layers and hidden strata, the infinite go-before of the present." 20 Once again Darwin's four postulates appear, this time applied to the evolution of language. In the following statement Whitman describes the gradual evolution of language over time (postulates one and two):

View'd freely, the English language is the accretion and growth of every dialect, race, and range of time, and is both the free and compacted composition of all ... is indeed a sort of universal absorber, combiner, and conqueror. The scope of its etymologies is the scope not only of man and civilization but the history of Nature in all departments, and of the organic Universe, brought up to date; for all are comprehended in words, and their backgrounds $(S A, 572)$.

Not only does language develop by absorbing differences over time, but all language has a "common descent" (postulate three). That is, language is "something arising out of the work, needs, ties, joys, affections, tastes, of long generations of humanity ..." $(S A, 573)$. Just as new species adapt to a new environment, new words arise due to the need to express new knowledge.

Whitman also applies Darwin's notion of natural selection to linguistic 
evolution. He envisions slang as a playful and creative force in language, capable of inducing change:

Slang, too, is the wholesome fermentation or eructation of those processes eternally active in language, by which froth and specks are thrown up, mostly to pass away; though occasionally to settle and permanently chrystallize $(S A, 573)$.

The use of slang is analogous to the means of generating diversity within a population; it introduces variety into language. After these variations are produced, the next step of selection takes place. Whitman writes: "In the processes of word-formation, myriads die, but here and there the attempt attracts superior meanings, becomes valuable and indispensable, and lives forever" ( $S A, 573)$. Many newly created words perish, but the few which gain "superior" meaning live on in a linguistic version of "survival of the fittest."

For Whitman, "nothing is more spiritual than words"- "those eluding, fluid, beautiful, fleshless, realities." 21 An individual, the culmination of eons of evolution, using language that contains all that has been absorbed over long ages, has to have a potent voice. Not only does the individual encompass all of the past biological and geological experience, but language includes all past human experience. Language used imaginatively is elevated to literature-the apex of the past, the reality of the present, and the promise of the future. Literary creation, then, is a poised moment in which the poet is capable of propelling the entire past and present into the future.

Whitman envisions literature as a shaping power in any nation. It is the "first-class" poets, philosophers, and authors who create the atmosphere from which the social institutions arise. And, according to Whitman, they now "must stamp ... the interior and real democratic construction of this American continent, to-day, and days to come." 22 In order to accomplish this, Whitman calls for "two or three really original American poets" - "national expressers" $(D V, 368)$ - to arise and create what Arthur M. Schlesinger, Jr. calls "archetypes of the American imagination" 23 and thus provide "compaction" and "moral identity" to America.

For Whitman, poetry and language are like genetic material - "they furnish the materials and suggestions of personality for the women and men" of a country $(D V, 392)$ - from which an embryonic Democracy will be developed. With this in mind, Whitman calls for a "new founded literature," "a literature underlying life, religious, consistent with science," a literature "teaching and training men" and "insuring to the States ... a race of perfect Mothers ..." $(D V, 372)$. Echoing Darwin's survival of the fittest and Orson Fowler's phrenological eugenics, Whitman insists: "Parentage must consider itself in advance. ... To our model, a clear-blooded, strong-fibred physique, is indispensable" $(D V, 397)$. Whitman, then, envisions the possibility of perfecting humankind through hereditary improvement. ${ }^{24}$

It is not surprising, then, that Whitman envisions a race of "perfect 
Mothers." What is astounding, however, is the means he chooses to accomplish this. Rather than selective breeding of flesh and blood human beings, Whitman creates an ideal literary model with the power to engender a new race of women fit to be mothers of the ideal democracy he has in mind. This new literature is "Not to chisel ornaments, / But to chisel with free stroke the heads and limbs of plenteous supreme Gods, that the States may realize them walking and talking" $(L G, 237)$. Whitman is close here to the Biblical sense of language, what Northrop Frye refers to as "hieroglyphic language"-language that creates and shapes reality. ${ }^{25}$ Out of language, Whitman creates a race of superbeings to inhabit the American continent.

But Whitman does not simply suggest the image of the artist chiseling a body. Pygmalion-like, he brings the image to life. He becomes the CreatorLover himself and boldly announces:

It is I, you women, I make my way,

...

I pour the stuff to start sons and daughters fit for these States, I press with slow rude muscle,

In you I wrap a thousand onward years,

On you I graft the grafts of the best-beloved of me and America, .

I shall demand perfect men and women out of my love-spendings,

I shall expect them to interpenetrate with others, as I and you interpenetrate now

I shall count on the fruits of the gushing showers of them, as I count on the fruits and the gushing showers I give now,

I shall look for loving crops from the birth, life, death, immortality, I plant so lovingly now (LG, 102-103).

Whitman, the progenitor, propels the "fatherstuff" of a great and vital future America into the mind of the reader through his poetry, which he refers to as the "offspring of my loins" ( $L G, 107) .{ }^{26}$

Walt Whitman, "the poet of the Body," and "the poet of the Soul," weaves the Darwinian theory of evolution into a religious, political, and poetic statement. This act in itself results in Whitman's refinements of his thoughts on the theory of evolution:

Running through prehistoric ages ... appear those venerable claims to origin from God himself, or from gods and goddesses - ancestry from divine beings of vaster beauty, size, and power than ours. But in current and latest times, the theory of human origin that seems to have most made its mark, (curiously reversing the antique,) is that we have come on, originated, developt, from monkeys, baboons ... are not both theories to be possibly reconciled, and even blended? Can we, indeed, spare either of them? Better still, out of them is not a third theory, the real one, or suggesting the real one, to arise? (DTF, 523-524).

In Democratic Vistas Whitman announces that the fulfillment of his thoughts on evolution will be the establishment of American bards and literary models 
which incorporate the best of science and religion and through which arise a superior breed of genuine Democratic Americans. Whitman's use of the Darwinian evolutionary analogue attempts to provide this "third theory" which reconciles the material and spiritual heritage of humankind.

\section{California State University, Chico}

\section{NOTES}

1 John Burroughs, Whitman: A Study (1896: rpt. Boston: Houghton Mifflin, 1924), 249; hereafter cited in the text as WS.

2 Joseph Beaver, Walt Whitman: Poet of Science (New York: King's Crown, 1951), hereafter cited in the text as PS; and Lenny Emmanuel, "Whitman's Fusion of Science and Poetry," Walt Whitman Review 17 (1971), 76.

3 Walt Whitman, Preface, 1855, to First Issue of Leaves of Grass, in Prose Works 1892, ed. Floyd Stovall (New York: New York University Press, 1964), 2:446-447; hereafter cited in the text as "PW 1855."

4 Walt Whitman, Preface, 1872, to "As a Strong Bird on Pinions Free," in Prose Works 1892, 2:462; hereafter cited in the text as "PW 1872."

5 Justin Kaplan, Walt Whitman: A Life (New York: Simon \& Schuster, 1980), 230. Because Whitman's first edition of Leaves of Grass was published four years before Darwin's The Origin of Species, most critics discount Darwin's influence on Whitman. However, Darwin's earlier essays of 1842 and 1844, although unpublished, were widely discussed. See Charles Darwin, "Charles Darwin's Sketch of 1842" and "Charles Darwin's Essay of 1844," both in Sir Gavin De Beer, ed. Evolution by Natural Selection (Cambridge: Cambridge University Press, 1958), 39-88, 89-254.

6 For other interpretations of Whitman's use of the theory of evolution, see Gay Wilson Allen, The Solitary Singer: A Critical Biography of Walt Whitman (New York: New York University Press, 1967); Joseph Warren Beach, The Concept of Nature in Nineteenth-Century English Poetry (New York: n.p., 1936); David Charles Leonard, "Lamarckian Evolution in Whitman's 'Song of Myself,' Walt Whitman Review 24 (1978), 21-28; and James T. F. Tanner, "The Lamarckian Theory of Progress in Leaves of Grass," Walt Whitman Review 9 (1963), 85-100.

7 See Harold Aspiz, Walt Whitman and the Body Beautiful (Chicago: University of Illinois Press, 1980), for an in-depth discussion of how Whitman's ideas on the body "derive from his keen observation of the health practices of his time and from his amateur acquaintance with medicine, popular eugenics, and health fads" (p. x). See also Arthur Wrobel, "Whitman and the Phrenologists: The Divine Body and the Sensuous Soul," PMLA 89 (1974), 17-23.

8 Orson S. Fowler, Hereditary Descent: Its Laws and Facts Illustrated and Applied to the Improvement of Mankind (New York: Fowler \& Wells, 1843), 127.

9 V. K. Chari, "Whitman and Indian Thought," in Western Humanities Review 13 (1959), 291-97.

10 Many critics believe that Whitman was not influenced much by Eastern writings, but gathered most of his mystical ideas from Emerson. But Emerson's sources include many from the East. It may be that Whitman was influenced by Eastern religion and philosophy in two ways-directly through his reading and indirectly via Emerson. In "Whitman's Copy of the Bhagavad-Gita," Walt Whitman Review 5 (1959), 12-14, George Hendrick provides "Whit- 
man's marginal notes and underscorings" in Whitman's copy of the Bhagavad-Gita, which was a'gift from Thomas Dixon. These notes indicate that Whitman was familiar with the Mahabharata and Ramayana as well.

11 Horace Traubel, With Walt Whitman in Camden (New York: n.p. 1914), 2:65; hereafter cited in the text as $W W C$. Later, Traubel mentions: "W. spoke tenderly of Darwin. Darwin is one of his loves that will last" (3:166).

12 R. M. Bucke, ed., Notes and Fragments (Folcroft, Pa.: Folcroft Press, 1899), Pt. II, item 1, p. 55; rpt. in Leaves of Grass, ed. Sculley Bradley and Harold W. Blodgett (New York: W. W. Norton \& Co., 1973), 763.

13 Walt Whitman, "Darwinism-Then Furthermore," Prose Works 1892, 2:524; hereafter cited in the text as DTF.

14 Ernst Mayr, "Evolution," Scientific American 239, No. 2 (1978), 47.

15 Charles Darwin, The Origin of Species By Means of Natural Selection or the Preservation of Favoured Races in the Struggle for Life, introd. Sir Julian Huxley (1859; rpt. New York: New American Library, 1958), 450; hereafter cited in the text as $O S$.

16 Walt Whitman, Specimen Days, in Prose Works 1892, 1:289; hereafter cited in the text as $S D$.

17 Charles Darwin, “Charles Darwin's Sketch of 1842,” Evolution By Natural Selection, introd. Sir Gavin De Beer (Cambridge: Cambridge University Press, 1958), 86. The brackets are Darwin's.

18 Loren Eiseley, Darwin's Century: Evolution and the Men Who Discovered It (New York: Doubleday \& Co., 1961), 98.

19 Here Whitman wholeheartedly embraces the ethnocentrism of Manifest Destiny which shaped Indian policy in the 19th century. This sounds like many of the Social Darwinists who used Darwin's theory of evolution, in particular the concept of "survival of the fittest," to justify racism and imperialism. But in the same conversation, several sentences later, Whitman says:

Do you tell me that amalgamation is likely? I do not see it. The American white and the Southern black will mix but not ally. I have considered the problem from all sides. It is wonderful the readiness with which French and Negro, or Spanish and Negro, will marry-interlock-and the results are always good. It is the same with the Injun and Nigger - they too will ask no questions: they, too, achieve equally fine reproductivities (WWC, 2:283).

If blacks and Native Americans are to be eliminated due to "the laws of the races," how can Whitman say that intermarriage with these races produces "fine reproductivities"? Whitman is part of the rampant ethnocentrism of his century, but he also-as he said he did-contradicts himself.

20 Walt Whitman, "Slang in America," Prose Works 1892, 2:577; hereafter cited in the text as $S A$.

21 Walt Whitman, An American Primer, ed. Horace Traubel (1904; rpt. San Francisco: City Lights, 1970), 1.

22 Walt Whitman, Democratic Vistas, in Prose Works 1892, 2:367; hereafter cited in the text as $D V$.

23 Arthur M. Schlesinger, Jr. and Morton White, eds., Paths of American Thought (Boston: Houghton Mifflin, 1963), 53. 
24 In "The Superman in Leaves of Grass," Walt Whitman Review 11 (1965), 85-100, James T. F. Tanner says that Whitman anticipates Nietzsche's concept of a "Superman."

25 Northrop Frye, "Literature, History, and Language," MMLA Bulletin (1979), 1-7.

26 Whitman's notion of jetting the "fatherstuff" of a new nation into the receptive reader fits well with what Gilbert and Gubar describe as the Western patriarchal notion of literary creation. Using his pen as "a metaphoric penis," he "fathers his text just as God fathered the world." See Sandra M. Gilbert and Susan Gubar, The Madwoman in the Attic: The Woman Writer and the 19th-Century Literary Imagination (New Haven: Yale University Press, 1979), 3-4. 